\title{
Környezeti informatika és a fenntartható információs társadalom víziója
}

A tanulmány a kibontakozó információs társadalom és a fenntarthatóság mint cél közötti kapcsolatokat tárgyalja. Hogyan járulhat hozzá az információs technológia a fenntartható fejlődéshez? Melyek az információs társadalom lehetőségei és kockázatai a fenntarthatóság mint elérendő cél szempontjából? A szerző az információs és kommunikációs technológiák (IKT) és a fenntarthatóság közötti kölcsönhatások két fő területét, nevezetesen a környezeti információk feldolgozásával foglalkozó környezeti informatikát (Environmental Informatics) és az információs társadalom müködésében releváns szerepet játszó technológiák (röviden: információs társadalmi technológiák) hatásait vizsgálja.

Kulcsszavak: információs és kommunikációs technológiák, fenntarthatóság, környezeti informatika

\section{Szerzői információ:}

\section{Lorenz M. Hilty}

Az informatika professzora, a svájci Szövetségi Anyagvizsgálati és Kutatólaboratórium (Empa) technológia- és társadalomkutatási részlegének vezetóje. Egyetemi oktatómunkája mellett 2000tól az Empa „Fenntartható Információs Társadalom” címú kutatási projektjét irányította. Fóbb kutatási területei: az információs és kommunikációs technológia ökológiai és szociális aspektusai, továbbá az információs, nano- és biotechnológiák és a kognitív tudományok közeledése.

Így hivatkozzon erre a cikkre:

Hilty, Lorenz M.. „Környezeti informatika és a fenntartható információs társadalom víziója.” Információs Társadalom IX, 3. szám (2009): 6-26.

$=\quad$ https://dx.doi.org/10.22503/inftars.IX.2009.3.1

A folyóiratban közölt müvek

a Creative Commons Nevezd meg! - Ne add el! - Így add tovább! 4.0

Nemzetközi Licenc feltételeinek megfelelöen használhatók. 
Lorenz M. Hilty

\section{Környezeti informatika és a fenntartható információs társadalom víziója ${ }^{1}$}

\section{Háttér}

A fenntarthatóság iránti igény és az információs társadalom kialakulása széles körben vitatott kérdéseket vet fel. Mi köze van azonban az egyiknek a másikhoz? Mielốtt megindokolnánk azt a meggyoózốdésünket, hogy ez a két témakör ténylegesen szorosan összefügg, szeretnénk röviden körvonalazni, hogy mit értünk rajtuk. Az információs társadalom kifejezést azoknak a társadalmi változási folyamatoknak az eredményeként értelmezzük, amelyeket az egyre olcsóbbá váló információs és kommunikációs techológiák (IKT) gyors terjedése gerjeszt, és amelyek révén fokozatosan egy posztindusztriális társadalom irányában haladunk elốre. Azt, hogy a jövóbeli információs társadalom milyen formát fog ölteni, aligha tudja bárki is megjósolni. Egy dolog azonban biztos: az eredmény nagyrészt attól függ, hogy ezt a fejlődést mi magunk hogyan befolyásoljuk.

A fenntartható fejlódés (vagy röviden: fenntarthatóság) mértékadó meghatározását a Környezet és Fejlődés Világbizottság (World Commission on Environment and Development, $W C E D)$ fogalmazta meg: a fenntartható fejlódésnek „anélkül kell kielégítenie a jelen szükségleteit, hogy veszélyeztetné a jövő generációk lehetôségeit saját szükségleteik kielégítésére" (WCED, 1987). A fenntarthatóság így meghatározott értelmében a gazdasági fejlődés céljának a források igazságos megosztását kell tekintenünk mind az egyes generációkon belïl, mind az egymást követô generációk között.

Az ENSZ 1992-ben „Környezet és Fejlődés” címmel Rio de Janeiróban tartott konferenciáján (United Nations Conference on Environment and Development, UNCED) a fenntartható fejlődés célkitúzése vált a nemzetközi környezeti és fejlesztési politika legfontosabb kérdésévé. Széles körben elfogadottá vált az a felfogás, hogy a fenntarthatóságnak környezeti, társadalmi és gazdasági dimenziói is vannak: ezek tudományos alapjainak kidolgozása és továbbfejlesztése érdekében számos nemzeti és nemzetközi kutatási program és egyéb kezdeményezés indult útjára.

Az 1990-es években a fenntarthatóság fogalmának kétféle szélsôséges értelmezése alakult ki:

- Az erós fenntarthatóság feltétele a teljes természeti tốke megórzése, vagyis az iparnak mint a természeti források felhasználójának csakis a természeti tóke „kamataiból” szabad merítenie. Következésképpen be kell tiltani a nem megújuló eróforrások

${ }^{1}$ E tanulmány elsố része L. N. Hilty és T. F. Ruddy „Fenntartható információs társadalom felé” ('Towards a Sustainable Information Society) címú cikkén alapul, amely elôször az Informatik/Informatique c. folyóirat 4/2000. számában jelent meg (2-9). 
kihasználását, és a megújuló forrásokat is csak azok újjátermelésének arányában szabad felhasználni. ${ }^{2}$

- A gyenge fenntarthatósághoz elegendố az emberi tevékenységból eredố tớke és a természeti tóke összesített értékének megórzése. ${ }^{3}$ Ez annyit jelent, hogy a természeti tốke tetszés szerint csökkenthetố, ha ezt kompenzálja az ember által létrehozott tốke növekedése.

A politikai viták során ismételten világossá vált, hogy a járható út e két szélsőség között húzódik, és ennek megtalálására kell állandóan törekedni. A fenntarthatóság elérése tehát a jövoóre orientált társadalmi folyamat, amelyben a tanulás, a kutatás és a strukturáló törekvések bizonyos mértékú sötétben tapogatózás, nagyfokú bizonytalanság és különféle konfliktusok mellett is fontos szerephez jutnak, vagyis a fenntarthatóság „szabályozó eszme” (Minsch et al. 1998).

Miközben azonban a legkiválóbb kutatók újabb és újabb kutatási programokon töprengenek azoknak a kisebb-nagyobb változásoknak a kimutatására törekedve, amelyek közelebb juttathatják a társadalmat a fenntarthatóság eléréséhez, a világ gyorsan változik az IKT fokozódó hatásai alatt. Ez a változási folyamat, melynek során világunk információs társadalommá alakul át, elvileg elvezethet ahhoz, hogy az anyagi termékek funkcióit bizonyos mértékig az információ és a tudás váltsa fel életünkben. Emellett az úgynevezett dematerializálódási folyamat mellett azonban a változási trend magában foglalja a gazdaság fokozódó globalizálódását is, ami eddig az anyagi termékek és az emberek növekvô mértékú fizikai helyváltoztatásával járt együtt. Végül pedig az információs társadalom egyúttal az innovációs folyamatok felgyorsulását is jelenti, és így a változás a meglevô dolgoknak az újak belépése révén bekövetkezó, egyre gyorsabb ütemú leértékelődésével jár együtt, legyen szó akár hardverról vagy szoftverról, technikai termékekról vagy emberi készségekról és tudásról.

Az információs társadalom kialakulásának sebességét Moore törvénye határozza meg, amely kimondja, hogy az IKT-eszközök teljesítménye 18-24 hónaponként megkétszerezốdik. Ez mindeddig figyelemreméltóan pontos elôrejelzésnek bizonyult, nem csupán a processzorok sebességét, hanem a számítógépek memóriakapacitását és a hálózatokban folyó adatátvitel gyorsaságát tekintve is.

Ennek eredményeként az emberek egyre nagyobb számítástechnikai teljesítmény és adatátviteli kapacitás előnyeit használhatják ki anélkül, hogy ez több helyet, több energiát vagy nagyobb költségeket igényelne, s erre a technikai infrastruktúrára alapozva szinte naponta új szolgáltatások jönnek létre, amelyek életünk egyre több és több területére hatolnak be.

2 A fenntarthatóság „erôs” kritériumai kizárják azokat a forgatókönyveket, amelyek szerint véges eróforrások kiaknázásával „gazdasági fellendülés jön létre, olyan jelentôs technikai haladással együtt, melynek révén ismét takarékoskodni lehet azokkal, a megújuló források akkorra lehetôvé váló hasznosításának köszönhetốen (Meyer-Abich, 2001, 297).

3 „Így megengedhetố az utóbbinak az elóbbire való széles körú felcserélése, például a tengerpartok helyett élvezhetjük az úszómedencéket, a történelmi régiók helyett látogathatunk szabadidôparkokat, s a természetjárás szerepét átvehetik a fitneszközpontok" (Meyer-Abich 2001, 296). 
1. táblázat

Aะ IKT és a fenntarthatóság környezeti dimenziója közötti kölcsönhatások kategóriái

\begin{tabular}{|c|c|c|}
\hline \multirow{6}{*}{$\begin{array}{l}\text { Környezeti infor- } \\
\text { mációk feldolgozá- } \\
\text { sa (Environmental } \\
\text { Information Processing, } \\
\text { EIP) }\end{array}$} & \multirow{3}{*}{$\begin{array}{l}\text { Állami szektor: az állami hatóságok által } \\
\text { múködtetett környezeti információs } \\
\text { rendszerek (Environmental Information } \\
\text { Systems, EIS) }\end{array}$} & $\begin{array}{l}\text { A közjavak állapotának tuda- } \\
\text { tosítása a közvéleményben }\end{array}$ \\
\hline & & $\begin{array}{l}\text { A politikai döntések elófel- } \\
\text { tételei }\end{array}$ \\
\hline & & $\begin{array}{l}\text { A környezetpolitika végrehaj- } \\
\text { tási eszközei }\end{array}$ \\
\hline & \multirow{3}{*}{$\begin{array}{l}\text { Magánszektor: környezetkezelési } \\
\text { információs rendszerek (Environmental } \\
\text { Management Information Systems, EMIS) }\end{array}$} & $\begin{array}{l}\text { A jogi szabályozás figyelem- } \\
\text { bevétele }\end{array}$ \\
\hline & & $\begin{array}{l}\text { Beszámolási kötelezettség } \\
\text { a környezeti hatásokról az } \\
\text { érintetteknek }\end{array}$ \\
\hline & & $\begin{array}{l}\text { Ökohatékonyság és az anyag- } \\
\text { áramlások kezelése }\end{array}$ \\
\hline \multirow{2}{*}{$\begin{array}{l}\text { Információs társa- } \\
\text { dalmi technológiák } \\
\text { (Information Society } \\
\text { Technologies, IST) }\end{array}$} & $\begin{array}{l}\text { A gazdaság anyagigényességére gyakorolt } \\
\text { közvetlen hatás }\end{array}$ & $\begin{array}{l}\text { Az IST-termékek életciklusai- } \\
\text { nak anyagigénye }\end{array}$ \\
\hline & $\begin{array}{l}\text { A gazdaság anyagigényességére gyakorolt } \\
\text { közvetett hatás }\end{array}$ & $\begin{array}{l}\text { Helyettesítési lehetôségek, } \\
\text { optimalizációs lehetôségek, } \\
\text { indukciós potenciál }\end{array}$ \\
\hline
\end{tabular}

\section{A környezeti információk feldolgozása}

A környezeti információk feldolgozására szolgáló számítógépes rendszerek az 1970es évek óta vannak használatban. Ezekben a rendszerekben az alkalmazások széles skálájával találkozunk, beleértve a monitorozás és az ellenórzés, az információkezelés, az adatelemzés, valamint a tervezés és a döntéstámogatás eszközeit egyaránt. Az ilyen típusú rendszerek átfogó neveként a „környezeti információs rendszerek” (Environmental Information Systems, EIS) kifejezés használatos (Günther 1998, Rautenstrauch és Patig 2001, Hilty et al. 2005). Az informatika fejlődése felbecsülhetetlen mértékben növelte a természetben lejátszódó biológiai, kémiai és fizikai folyamatok elemzésére való képességeinket. Ugyanakkor a környezeti változók körében felmerülő problémák bonyolult természete nagy kihívás az informatika számára. A kölcsönös ösztönzés folyamatában alakult ki a „környezeti informatika” névvel ismert speciális tudományág, melyben a számítógép-tudomány különféle eredményei - például az adatbázisrendszerek, földrajzi információs hálózatok, modellezési és szimulációs eljárások, tudásalapú rendszerek és 
neurális hálózatok - kombinálódnak egymással, különös tekintettel a környezeti problémákra való alkalmazási lehetóségeikre (Avouris és Page 1995, Page és Hilty 1995, Hilty et al. 2006). A környezeti informatika körében folyó munka egyes típusai az alábbiakban leírt alkalmazási területek szerint tekinthetók át.

\section{Alkalmazások az állami szektorban}

A természeti környezetre vonatkozó információk feldolgozására az állami szektorban használt alkalmazások már a számítástechnika elterjedésének kezdetétól fogva folyamatosan fejlódnek. Szimulációs modelleket például a vízellátás területén már az 1950-es években is használtak. A legfejlettebb országokban ma kifinomult monitorozási rendszereket alkalmaznak, amelyek rendszeresen naprakész információt nyújtanak a környezet állapotáról. Az adatok egy részét teljesen automatizált telemetriai hálózatokban gyújtik, amelyek a levegó és a víz minôségének, valamint a radioaktivitás szintjének monitorozására szolgálnak. A telemetriai eszközök (az adott közegben, például a vízben vagy a levegóben elhelyezett automatikus szenzorok) adatokat továbbítanak a rendszerint helyhatósági, regionális vagy országos környezeti ügynökségek által múk ödtetett központi ellenốrzố egységekhez. Ezen a területen újabban jelentôs elốrehaladás történt a nagy kiterjedésú szenzorhálózatok fejlődésének köszönhetốen (Swiss Experiment, 2008). A környezeti adatok egy másik részét egyre nagyobb teljesítményú, távirányított érzékelő múszerek útján szerzik be, és a légi- vagy múhold-felvételekról származó földrajzi információkkal összevetve dolgozzák fel.

A környezeti információs rendszerek az állami szektorban legalábbis három igen fontos funkciót töltenek be (lásd 1. táblázat, jobb oldali oszlop).

\section{A közvélemény tájékoztatása}

Az információs ügynökségeket sok országban törvény kötelezi a környezet megfigyeléséból származó adatok közzétételére. Az ilyen adatok nyilvánosságra hozatala révén a közjavak (például a légkör vagy az üdülési régiók) állapota jobban tudatosodik a közvéleményben, ami egyébként nem történne meg, mivel a meghatározásuk értelmében áruba nem bocsátható közjavakra nézve árcédulák útján nem adható tájékoztatás. A környezeti adatok közzétételének más fontos hatásai is vannak: ennek alapján például az állampolgárok maguk is megítélhetik a kormány környezeti politikájának sikerét vagy kudarcát.

\section{Döntéstámogatás}

A környezeti információk nélkülözhetetlen alapot jelentenek olyan politikai döntések meghozatalához, amelyek kihatással vannak a természeti környezetre, vagy megfordítva, a környezet állapotától függenek. A döntéstámogatás nem csupán az adott status quo megítélésére vonatkozó információk nyújtásából áll, hanem magában foglal prognózisokat (például az ózonrétegre is kiható nyári füstködökre vonatkozó rövid távú elôrejelzéseket), továbbá felöleli a különféle szóba jöhetố alternatívák (forgatókönyvek, „mi-lenne-ha” típusú kérdések) hatásainak mérlegelését is. A környezeti infor- 
matika fontos hozzájárulást nyújt a döntéstámogatáshoz azáltal, hogy módszereket és eszközöket biztosít a modellezéshez, a szimulációhoz. Az ilyen rendszerek központi szerepet játszanak többek között a klímaváltozás és abban az ember szerepének modellezésében, segítve az ezzel kapcsolatos döntések meghozatalát.

\section{Környezetpolitikai intézkedések}

A környezetpolitika eszközeit csak akkor lehet hatékonyan alkalmazni, ha folyamatosan pontos és naprakész információ áll rendelkezésre. A környezeti informatikai rendszerek segítenek a szabályok megszegésének felkutatásában (például az illegális kibocsátások forrásának kinyomozásával), közremúködnek a meghozott intézkedések sikerének monitorozásában, s válságok és katasztrófák esetén biztosítják az azonnali cselekvéshez szükséges információkat. Példaként ismét a klímapolitika területét idézhetjük. Az 1992. évi UNFCCG-egyezmény kötelezố erejét tovább erôsítette az 1997-ben hozzá csatolt kiotói protokoll. Ez jó példát nyújt arra, hogy az egyezmények hogyan válnak a gyakorlatban nemzetközi törvénnyé, egyre nagyobb részletességgel meghatározva az elfogadott környezetpolitika végrehajtását szolgáló intézkedéseket is. Az egyezmény elő́rija nemzeti adatbázisok létrehozását és folyamatos fenntartását, amelyek az üvegházhatású gázok, elsôsorban a széndioxid és a metán kibocsátásának mértékét tükrözik a protokollt aláíró és ratifikáló valamennyi országban. Ezek az adatbázisok nélkülözhetetlenek az évi kibocsátási szintek nyomon követéséhez.

\section{Alkalmazások a magánszektorban}

A környezeti informatikai rendszereket az 1990-es évek elejéig szinte kizárólag az állami szektorban használták fel. Az 1990-es években azonban kialakult az olyan szoftverrendszerek piaca, amelyek a vállalatok környezetgazdálkodási tevékenységét támogatják: ezek „környezetkezelési információs rendszerek” (Environmental Management Information Systems, EMIS) névvel váltak ismertté (Hilty és Rautenstrauch 1997). A kezdeti idôszak után, amikor az elsó ilyen rendszereket még csak egyes vállalatok operatív tevékenységeinek támogatására fejlesztették ki, ma az a trend érvényesül, hogy a környezeti információkat felhasználják a több területet érintố stratégiai döntések meghozatalakor, és beépítik az általánosabb célú alkalmazásokba is - a hatékony környezetkezelés egyre inkább megköveteli a stratégiai vállalati hálózatok létrehozását (Hilty et al. 2000a). Ma a legtöbb EMIS fontos szerepet tölt be a következố területeken (lásd 1. táblázat, jobb oldali oszlop).

\section{Jogi szabályozás}

Elôször is, a környezetkezelési információs rendszerek elősegítik a törvények és szabályozások betartását azáltal, hogy áttekintést nyújtanak a környezettel kapcsolatos szabályokról a bonyolult jogi szabályozási keretekben (Riekert és Kadric 1997). Másodszor, az információs rendszerek segítik a felsố vezetóket a saját vállalatuknál a környezeti szabályozások szempontjából releváns fejlemények feltárásában és megértésében. 
Ilyen típusú alkalmazásokra adnak lehetôséget például a vállalaton belüli kibocsátás monitorozására és az anyagáramlások modellezésére szolgáló rendszerek.

\section{Környezeti hatások és fenntarthatóság}

A környezetet vagy a fenntarthatóságot érintő hatásokról tájékoztató információs rendszerek lehetôvé teszik a vállalatok számára, hogy a környezeti hatások és kockázatok tekintetében eleget tegyenek számos beszámolási kötelezettségüknek a múködésük által érintett állami és önkormányzati szervek, bankok, biztosítók, beszállítók és fogyasztók, valamint alkalmazottaik, szomszédaik és a lakosság tekintetében. Az egyes vállalatokon belül számos szoftvert fejlesztettek ki a környezeti vagy fenntarthatósági jelentések elkészítésének támogatására. Az utóbbi években megnyilvánuló tendencia jegyében a környezeti hatások jelzésére szolgáló szoftvereket alkalmassá teszik az interneteken való felhasználásra és az adatoknak a leányvállalatokkal és az alkalmazottakkal való megosztására, továbbá meghatározott, szúkebb adatállományok nyilvánossá tételére az érdekelt résztvevók, például a beszállítók szélesebb köre számára is. Az ilyen html- vagy xml-alapú megoldások automatikusan képesek kiemelni valamely adatbázisból azokat az adatokat, amelyek elég nyilvánosak ahhoz, hogy az interneten is közzétehetốk legyenek (Isenmann 2005).

\section{Ökohatékonyság}

A környezeti információkezelési rendszerek elősegítik az ökológiai hatékonyság (röviden: öko-hatékonyság) javítását. Ez a kifejezés valamely funkcionális egyedi termék vagy szolgáltatás (például egy csésze kávé vagy a mindennapi tiszta öltözék) mint output és az ennek elóállítására ráfordított anyag- és energiamennyiség mint input közötti arányt jelöli. Annak a meghatározására, hogy az érték-hozzáadási lánc melyik szakaszában lehet fokozni az ökohatékonyságot, az úgynevezett életciklus-értékelés (Life Cycle Assessment, LCA) szolgál, melynek során megvizsgálják egy-egy termék vagy szolgáltatás egész életciklusát „a bölcsốtól a sírig”, vagyis a természeti erôforrásoknak a környezetból való kivételétól kezdve valamennyi termelési és hasznosítási fázison keresztül egészen a hulladékok elhelyezéséig, és értékelik ennek ökológiai vonzatait. A termékek életciklusait, magukat a vállalatokat és a termelési eljárásokat egyaránt az ökohatékonyság szempontjából optimalizálható anyagáramlási rendszereknek lehet tekinteni. Az anyagáramlás ilyen értelemben különbözố szinteken értékelhetô, a legfelsố stratégiai szinttól a közvetlen termelési szintekig, beleértve például

- stratégiai vállalati hálózatok (különösen újrafelhasználási hálózatok) kiépítését;

- az LCA felhasználását a meglevố termékek vagy eljárások alternatív megoldásainak rangsorolására a termékek vagy alkatrészek elkészítése vagy megvásárlása szempontjából;

- a „környezettudatos tervezést” (Design for the Environment, DFE) a termék egész életciklusa folyamán végbemenó anyagáramlások és a létrejövố környezeti kockázatok csökkentésének céljával; valamint 
- az eljárások valós idejû ellenórzését a kibocsátások minimalizálása vagy az energiahatékonyság növelése érdekében.

Az LCA és általánosabb értelemben az anyagáramlás-kezelés támogatásához különféle szoftverrendszerek állnak rendelkezésre. A legrugalmasabb megoldás a felhasználók támogatása saját anyagáramlási rendszereik modellezésében és értékelésében. Ennek egyik példája az anyagáramlási hálózatok alapján kidolgozott Umberto elnevezésû́ kereskedelmi szoftver, melynek reprezentációs formalizmusát a Petri-hálózatokból vezették le (Schmidt et al. 1997).

Az „ökohatékonyság” terminust néha összevont értelemben, mintegy rövidítésként alkalmazzák mind a gazdasági, mind a környezeti hatékonyság kifejezésére. Ezt teszi például az Üzleti Világtanács a Fenntartható Fejlődésért (World Business Council for Sustainable Development, WBCSD) elnevezésú szervezet, amely nemzetközi szinten szorgalmazza az ökohatékonyság elérésére irányuló törekvéseket. ${ }^{4}$

\section{Információs társadalmi technológiák}

Információs társadalmi technológiákon (angolul: Information Society Technologies, $I S T)^{5}$ azokat a technológiákat értjük, amelyeknek a felhasználása eloosegíti az információs társadalomhoz vezetố átmenet alapját képezố változásokat. Ezek az IKT részhalmazát alkotják, és speciális lehetôségeket rejtenek magukban a mély társadalmi változások elérésére. ${ }^{6}$

A fenntarthatóság szempontjából az információs társadalmi technológiák legfontosabb jellemzóje az, hogy mennyiben tudnak hozzájárulni a gazdasági folyamatok anyagigényességének csökkentéséhez (beleértve a termelést, a fogyasztást és a hulladék-kezelést, valamint az ezzel összefüggố logisztikai folyamatokat, például a szállítást és a raktározást is). A „anyagigényesség” (material intensity) kifejezést az ebben a témában folyó diskurzusban igen széles értelemben használják. A terminus a valamely termék vagy szolgáltatás (vagy makroszinten a GDP) létrehozásával együtt járó anyagés energiaátviteli folyamatokra utal. Az anyagigényesség csökkentése egy adott termék vagy szolgáltatás azonos minôségben való előállítása vagy akár tökélesítése mellett lényegében ugyanazt jelenti, mint az ökohatékonyság növelése.

Az anyagigényesség jelentôs csökkentését (más szóval az ökohatékonyság növelését) dematerializációnak is nevezik. A dematerializáció valamely fenntartott vagy tökéletesitett termék vagy šolgáltatás kevesebb anyag-, illetve energiafelhasználással való létrehosásaként definiálható. ${ }^{7}$

${ }^{4}$ http://www.wbesd.org

${ }^{5}$ A továbbiakban a magyar szakirodalomban is elterjedt angol rövidítést használjuk. - A ford.

${ }^{6}$ Az IST angol terminust az Európai Bizottság vezette be, amikor a „Felhasználóbarát információs társadalomért” elnevezésú programot az Ötödik Keretprogram (FT5) négy tematikus programjának egyikéül jelölték ki. A Hetedik Keretprogram életbelépését követôen azonban ezt a kifejezést már mellózték. Mai perspektívából helyesebbnek túnik, ha inkább az IKT olyan pontosabban meghatározott fajtáiról beszélünk, amelyek szerepet játszanak a mély társadalmi változásokban, nevezetesen: Ambient Intelligence, Ubiquitous Computing vagy ,a dolgok internete” (The Internet of Things).

${ }^{7}$ Egyes szerzók a dematerializációt élesen megkülönböztetik az úgynevezett immaterializációtól - erre a kérdésre késóbb visszatérünk. 
Az információs társadalmi technológiák terjedése közvetlen és közvetett módon egyaránt kihatással van a gazdaságra:

- közvetlenül magának az IST-hardvernek a termelésén, felhasználásán és hulladékká válásán keresztül,

- közvetve pedig a szubsztitúciós vagy helyettesítési, optimalizációs és indukciós hatások révén.

A következókben az IST mindkét típusú hatásaival foglalkozunk.

\section{Közvetlen hatások}

Az információs társadalmi technológiák maguk is gyorsan változnak egyre rövidüló innovációs ciklusokban. Ma a személyi számítógépet tekinthetjük a legfontosabb eszköznek az IST körében, de ezt akár néhány éven belül könnyen felválthatják más technikai eszközök. A közlekedés telekommunikációs eszközökkel való kiváltásáról vagy a papír digitális adathordozókkal történố helyettesítéséról folyó vitákban - hogy csak két példát említsünk - rendszerint feltételezik, hogy a „virtuális” alternatívák kevésbé anyagigényesek, mint a konvencionális megoldások. Ezt a feltételezést azonban esetról esetre komolyan meg kell vizsgálni, ami egyebek között annyit jelent, hogy az adott hardvertermékek egész életciklusát kell értékelni (az LCA különösen fontos az elektronikai készülékek esetében).

Ezen a területen először 2000-ben gyújtöttünk össze bizonyos releváns adatokat (Hilty et al. 2000b). A források értékelése feltárta, hogy mindeddig csak a tévékészülékek, valamint a katódsugárcsöves monitorokkal múködô személyi számítógépek életciklusát vizsgálták, és a síkképernyốs kijelzóberendezések, a távközlési hálózatok, a mobiltelefonok és a múholdas kommunikáció eszközei tekintetében még mindig sok kérdés nyitva áll. A személyi számítógépeket illetoón a legjelentôsebb eredmény az volt, hogy a számítógépek életciklusa során a legtöbb anyag- és energiaráfordítás a termelés fázisában történik. A számítógépek elóállításához felhasznált anyagoknak csak kevesebb mint 2 százaléka - egy tanulmány szerint mindössze 0,1 százaléka - épül be magába a termékbe, a többi pedig gyártási hulladék. Az egyetlen személyi számítógép előállítására fordított energia (5-12 GJ) körülbelül tízszeresen meghaladja az átlagos felhasználási ciklus során elfogyasztott energia mennyiségét. ${ }^{8}$ Egy színes tévékészülék előállításához negyedannyi energiára van szükség, mint egy személyi számítógéphez. A kommunikációs hálózatokat tekintve úgy túnik, hogy ezek létrehozása és múködtetése - a személyi számítógépekével összehasonlítva - viszonylag kis részét teszi ki az IST-nek tulajdonítható ökológiai terhelésnek. Egy telefonvonal múködtetésének energiaigénye például megközelítóleg évi 100 kWh (0,36 GJ/a) nagyságrendú.

Egészében véve a vizsgálat eredményei azt mutatják, hogy az IST-hez nélkülözhetetlen alapvetố technológiák felhasználásának anyag- és energiaszükségletét nem szabad elhanyagolni, mivel befolyásolja az információs társadalom ökológiai kompatibilitását. Ennek mérlegelése csak még fontosabbá válik, ha tekintetbe vesszük, hogy

\footnotetext{
${ }^{8}$ Az asztali személyi számítógépek esetében az újabb vizsgálatok már jóval alacsonyabb arányokat állapítottak meg, ami azzal a ténnyel magyarázható, hogy a termelés energiafelhasználása hatékonyabbá, a tipikus felhasználási fázis pedig energiaigényesebbé vált.
} 
ezek a technológiák folyamatosan és egyre gyorsabban terjednek. Másrészt óvatosan kell kezelnünk ezeket az adatokat, nem feledkezve meg arról, hogy csupán egy pillanatfelvétel által rögzített helyzetet tükröznek, míg a technológia és az annak alkalmazására épülő gyártási folyamatok fejlődése elvileg nem látható eloóre.

\section{Közvetett hatások}

Az IST-nek a fizikai folyamatok világában kifejtett hatásait általában három fö típusba szokták sorolni. Ezt a felosztást eredetileg a távközlés által a közlekedési forgalomra gyakorolt hatások osztályozására vezették be, s így leginkább ennek a speciális esetnek a példáján keresztül világítható meg. Megjegyezzük azonban, hogy ezeket a kategóriákat általánosítjuk az IST minden fajtájára és azok mindenféle fizikai folyamatra gyakorolt hatásaira. A következó hatásokat különböztetjük meg:

- szubsztitúciós hatás (a fizikai forgalom helyettesítése távközléssel), lásához),

- optimalizációs hatás (a távközlés hozzájárulása a forgalmi rendszerek optimalizá-

- indukciós hatás (a távközlés igénybevétele következtében, például a termelés megosztott formáinak lehetôvé tétele révén létrejövô forgalom).

Vizsgáljuk meg a papírfogyasztás példáján, hogy ez a felosztás hogyan alkalmazható más területeken! A személyi számítógépnek az írógép modern formájaként és különösen az e-mail üzenetváltások, illetve a világhálón és az interneten keresztül elérhetố más szolgáltatások közvetítôjeként ténylegesen megvan az a potenciálja, hogy csökkentse a papírfogyasztást. Tengernyi szöveges és grafikus információ szerezhetô meg közvetlenül a képernyớról, amely sok esetben ténylegesen helyettesíti a papírt. Tapasztalható továbbá az optimalizációs hatás is, mivel ma például igen sok hibát ki lehet javítani, mielớtt egy-egy szöveget vagy képet első́ ízben kinyomtatnánk.

Mindazonáltal - mint az olvasó is tudhatja saját mindennapi tapasztalataiból - az indukciós hatás messze felülmúlja az egyéb hatásokat, mivel a mai személyi számítógépes és nyomtatási technológia lehetôvé teszi a felhasználó számára, hogy oldalak százait nyomtassa ki csupán néhány kattintás segítségével. Ennélfogva a papírfogyasztás tekintetében az IST - mindent egybevetve - hozzájárul az elmúlt hatvan év során megfigyelt általános növekedési trend fenntartásához (Ehrenfeld 1998). Az egy före jutó papírfogyasztást sok helyen komolyan számításba veszik a jólét egyik indikátoraként. A svájci napilapok a közelmúltban ünnepelték azt a tényt, hogy egy átlagos svájci állampolgár ma évente $240 \mathrm{~kg}$ papírt fogyaszt, és ez a trend csak erósödik. Ez a hatás volna az, amit az információs társadalomtól vártunk?

Napjainkban valószínúleg mégis a közlekedés az a legfontosabb terület, ahol az IST szubsztitúciós és optimalizáló hatásait túlkompenzálják az indukciós hatások. Míg a távmunkából és a távszolgáltatások különféle fajtáiból eredô helyettesítési hatások (például a szoftverek automatikus „karbantartása” vagy az „e-bankolás” területén) csökkenthetik a fizikai forgalmat, a piacok globalizálódásából és a távközlési hálózatoknak köszönhetoón megvalósuló megosztott termelési formákból eredô indukciós hatások világosan láthatóan eltérnek a fenntarthatósághoz vezetố úttól.

Az 1. ábra az IST hatásainak összefüggéseit szemlélteti. 


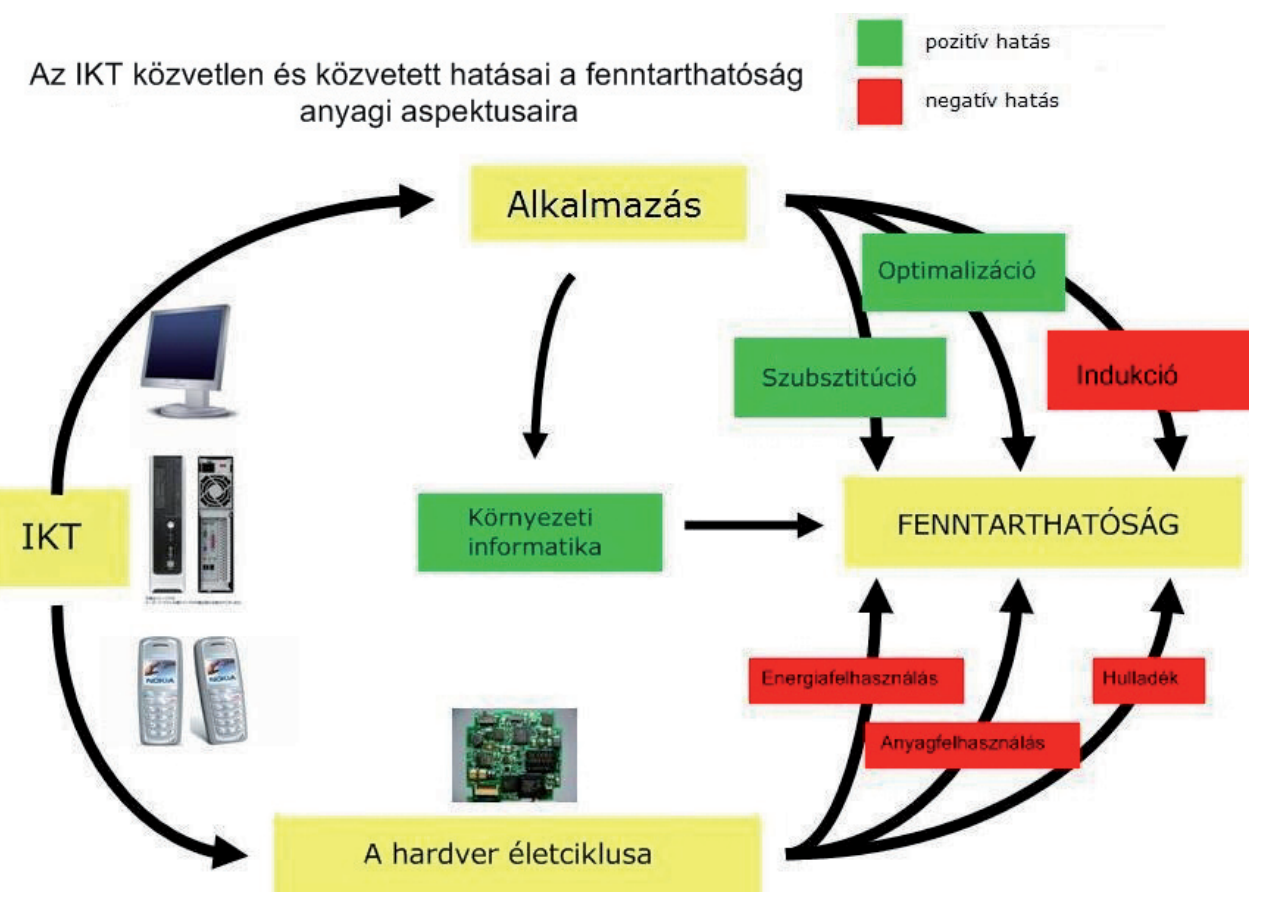

1. ábra

Az IKT közvetlen és közvetett hatásai a fenntarthatóság anyagi aspektusaira

\section{A visszacsapó hatás}

A várakozásainknak ellentmondó trendek - például a papírfogyasztás és a közlekedési forgalom növekedése - a „visszacsapó hatás” (rebound effect) jelenségére nyújtanak példát. Ezt a hatást eredetileg az energiaszektorban fedezték fel, és abban nyilvánul meg, hogy a hatékonyság növekedésével létrehozott nyereséget kiegyenlíti vagy akár túlkompenzálja a mennyiségi növekedés (Binswanger 1999). Az energiahatékonyság (a bruttó hazai termék és a teljes energiafogyasztás hányadosa) az erôsen fejlett országokban az elmúlt évtizedek során folyamatosan növekedett, évente körülbelül egy százalékkal. Ezt a „megtakarítást” azonban túlkompenzálja a bruttó hazai termék (GDP) növekedése, úgyhogy abszolút értékben egyre több energia felhasználása történik minden évben.

Ez a helyzet aligha fog változni az információs társadalomban: az IST révén elért valamennyi szubsztitúciós és optimalizációs hatás új szabadságfokokat hoz létre, amelyeket a mennyiségi növekedésre használnak fel. Nagyon gyakran elófordul, hogy a régi technológiák felhasználása is tovább növekszik, miközben az újakat ezek kiegészítéseként alkalmazzák, hozzájárulva a régi technológiákkal addig elért határok kiterjesztéséhez. F. J. Radermacher megfogalmazásában: „A 'csapda', amelybe a technikai haladás során újból 
és újból beleestünk, voltaképpen abban áll, hogy valami (a visszacsapó hatás) mintegy 'ráadásként' mindig hozzáadódik ahhoz, ami azelốtt is folyt. Ez a hatás elốrejelzi, hogy a piaci erók - az emberiség látszólag korlátlan fogyasztási kapacitására építve - arra fogják felhasználni az új technológiákat, hogy egyre több és több erôforrás kiaknázásával mind több tevékenység és funkció ellátását tegyék lehetôvé új és még újabb szolgáltatások és termékek létrehozásával” (Radermacher 1996). A visszacsapó hatás legszemléletesebb példáját maguk az információs és kommunikációs technológiák nyújtják. A már említett Moore-törvény szerint a digitális elektronika fejlódése három-négy év alatt a gyártástechnológiai eljárások négyszeres arányú dematerializálódásával jár együtt. Felmerül a kérdés, hogy ez a folyamatos, drámai mértékú dematerializálódás miért nem vonja magával az IST által létrehozott teljes energia- és anyagáramlás megfelelő csökkenését. A helyzet ugyanis ennek éppen az ellenkezóje: az elektronikai iparágak részesedése az energiafogyasztásból továbbra is növekszik, és az elektronikus hulladék mennyisége azt jelzi, hogy az anyagfelhasználás is hasonló ütemben emelkedik.

A jelenlegi gazdasági keretfeltételek között legvalószínúbb forgatókönyv 2015-ig az IST-piac folytatódó exponenciális bôvülését jelzi, ami a használatban levô IST-eszközök összes fizikai tömegének lineáris növekedését eredményezi (Hilty et al. 2000b).

Az elmondottakból azt a következtetést vonhatjuk le, hogy az ökohatékonyság vagy a dematerializáció irányában végbemenố technikai fejlődés szükséges, de nem elégséges feltétel a fenntarthatóság mint cél megközelítéséhez. Ugyanakkor a politikának olyan globális keretfeltételeket kell megteremtenie, amelyek a ritka ökológiai eróforrások világszinten optimális allokációját biztosítják piaci mechanizmusokon keresztül. A keretfeltételek megváltoztatásának szükségességét hangsúlyozza az Információs Társadalmi Fórum is: „A visszacsapó hatást a globalizált gazdaságban csakis az korlátozhatja, ha a politikusok megfelelő és a világgazdasági rendszer szerves részeként funkcionáló társadalmi és ökológiai védókorlátokat állítanak fel. Az ilyen védókorlátokat helyi szinteken országos és regionális keretfeltételek formájában kell bevezetni” (ISF 1998, 22).

\section{Az ökohatékonyságtól az új életstílusokig}

Az ökohatékonyság vagy dematerializáció mögött az a megfontolás húzódik meg, hogy a végfelhasználó számára megcélzott eredmény mint „funkcionális egyedi termék vagy szolgáltatás" sem mennyiségileg, sem minôségileg nem változik, miközben az output biztosításához vezetố folyamat fizikai inputja változik, éspedig csökken. Az életciklus-értékelés ( $L C A$ ) szakterületén bizonyos „funkcionális ekvivalencia” feltételezésével élnek. A funkcionális ekvivalencia azonban nehezen értelmezhetố fogalom. Még ha olyan egyszerú dolgok összehasonlítását végzik is egy-egy $L C A$-vizsgálat során, mint amilyenek például az italok különféle csomagolásai, kétséges, hogy az adott csomagolási módok funkcionálisan valóban ekvivalensnek tekinthetók-e. Ezenkívül a funkcionális ekvivalencia fogalma az IST esetében félrevezethetố lehet, amikor virtuális és valós alternatívákat kell összehasonlítani egymással. Ez jellemzó a szubsztitúció esetére is, amikor a korábbi fizikai funkciókat tisztán információs szolgáltatások helyettesítik. ${ }^{9}$

\footnotetext{
${ }^{9}$ Ezt a fajta változást nevezik néha „immaterializációnak”, szembeállítva a „dematerializációval”.
} 
Vizsgáljuk meg a távmunka példáját! Funkcionálisan egyenértékú lehet-e valaha is az otthoni munka a munkahelyeken végzett munkával? Úgy véljük, hogy az emberek nem azért végeznek távmunkát, mert a távjelenlét funkcionálisan egyenértékú a fizikai jelenléttel, hanem azért, mert jelentôs különbség van a kettô között. A fizikai folyamatok virtuális helyettesítối sohasem lesznek funkcionálisan egyenértékúek a fizikai folyamatokkal, és mindig lesznek bizonyos elónyeik és hátrányaik az elóbbiekhez képest. A funkcionális ekvivalencia követelménye félrevezetố, mivel tagadja a virtuális alternatíva másságát, más karakterét. Az információs társadalmi technológiák éretté válásuk során olyan virtuális alternatívákat biztosítanak, amelyek azért lépnek be életünkbe, mert konvencionális megfelelóiktốl eltéró követelményeknek tesznek eleget. Lehet, hogy csupán a környezeti megtakarítások érdekében az emberek nem változtatják meg az életstílusukat, de a kibervilágban elérhetô bizonyos funkcionális elốnyök erôsebben motiválhatják óket.

\section{Az IKT hatásai a fenntarthatóságra - fogalmi keretek ${ }^{10}$}

A 2. táblázatban bemutatott mátrix megkísérli integrálni a használatban levố terminológiákat. Ez különösen az elsố-, másod- és harmadrendú hatások osztályozására vonatkozik, beleértve a termék életciklusának fázisokra bontását, a szubsztitúciós, optimalizációs és indukciós hatások megkülönböztetését, valamint az olyan, különbözố kontextusokból származó fogalmakat is, mint például a strukturális változás, a dematerializáció, a viszszacsapó hatás és a kritikus információs infrastruktúra. Az IST így felvázolt fogalmi keretrendszere széles perspektívából veszi számba az IKT hatásait, lehetôséget nyújtva egyrészt saját elgondolásaink új kontextusba helyezésére, másrészt teret adva a képzelóerô számára is. Minden érintett megtalálhatja benne azokat a pontokat, amelyeket - potenciálisan - az IKT pozitív hatásainak maximalizálása és a negatív hatások minimálisra csökkentése érdekében tett saját hozzájárulása foglalhat el.

Ezt a keretet normatív értelemben igyekeztem semlegesen tartani, csupán az „IKT mint a megoldás része” és az „IKT mint a probléma része” kategóriák alapulnak nyilvánvalóan értékítéleteken. Természetesen normatív döntés eredménye továbbá az is, hogy a fenntartható fejlődést olyan célnak tekintem, amelynek eléréséért érdemes küzdeni. A fogalmi keretek mindazonáltal nem határozzák meg eleve, hogy az ily módon értelmezett pozitív és negatív hatások mely esetekben és milyen feltételekkel válnak uralkodóvá. A következókben sorról sorra magyarázatokat fúzök a bemutatott mátrixhoz.

A táblázatban szereplő szövegek:

${ }^{10}$ A tanulmány második részében elmondottak a szerzô által „Az IKT-nak a fenntarthatósághoz való hozzájárulását befolyásoló tényezók" (Factors influencing the contribution of ICT to sustainability) címmel az ICT European Technology Platform (ETP) vezetóinek értekezletén 2008 februárjában Brüsszelben tartott előadásán alapulnak. European Commission DG Information Society and Media (INFSO). 
2. táblázat

Fogalmi keretek. Az IKT-nak a fenntarthatóság szempontjából releváns hatásai

\begin{tabular}{|c|c|c|c|c|}
\hline & IKT mint a megoldás része & $\begin{array}{l}\text { IK'T mint a pro } \\
\text { része }\end{array}$ & bléma & \\
\hline \multirow[t]{3}{*}{ Technológia } & \multirow{3}{*}{$\begin{array}{l}\text { Többet kihozni } \\
\text { kevesebból }\end{array}$} & \multirow{3}{*}{$\begin{array}{l}\text { Az IKT hard- } \\
\text { ver életcik- } \\
\text { lusa }\end{array}$} & Előállítás & \multirow{3}{*}{$\begin{array}{l}\text { Elsórendú (közvetlen) } \\
\text { hatások }\end{array}$} \\
\hline & & & $\begin{array}{l}\text { Felhasz- } \\
\text { nálás }\end{array}$ & \\
\hline & & & $\begin{array}{l}\text { Hulla- } \\
\text { dékkeze- } \\
\text { lés }\end{array}$ & \\
\hline \multirow[t]{2}{*}{ Alkalmazás } & Optimalizációs hatások & \multirow{2}{*}{\multicolumn{2}{|c|}{ Indukciós hatások }} & Másodrendú (közvetett) \\
\hline & Szubsztitúciós hatások & & & hatások \\
\hline \multirow{2}{*}{$\begin{array}{l}\text { Társadalmi vál- } \\
\text { tozás }\end{array}$} & \multirow{2}{*}{$\begin{array}{l}\text { Mély strukturális változás } \\
\text { a dematerializált gazdaság } \\
\text { irányában }\end{array}$} & \multicolumn{2}{|c|}{ Visszacsapó hatás } & Harmadrendú \\
\hline & & \multicolumn{2}{|c|}{$\begin{array}{l}\text { Új ktritikus infrastruk- } \\
\text { túra }\end{array}$} & \\
\hline
\end{tabular}

\section{Elsórendü (elsódleges) hatások}

Az elsốrendú hatások közé az IKT-hardver fizikai létezésének az olyan folyamatokból adódó hatásait soroljuk, amelyeken keresztül a hardver fejlesztése, gyártása, felhasználása és hulladékká válása a gyakorlatban ténylegesen megvalósul. ${ }^{11}$

A negatív oldalon az elsốrendú hatások körébe tartozik az életciklus valamennyi releváns hatása, beleértve az úgynevezett háttérrendszer hatásait (például a valamely adatfeldolgozási központ számára elektromos áramot biztosító erômú széndioxid-kibocsátását vagy a hardver előállításához szükséges értékes fémeket biztosító bányászati tevékenység környezetkárosító hatásait) is.

Nem szabad elfeledkeznünk arról, hogy az IKT-hardver gyorsan egymásra következố innovációs ciklusokban fejlôdik, tehát ennek a szektornak a lényegéhez tartozó jelenség, hogy a meglevố hardver gyakran lecserélődik a termékek következô generációjára, ami releváns környezeti hatásokkal járó anyag- és energiaáramlásokat indukál.

\section{Többet kihozni kevesebböl}

Az IKT-szektor más iparágakra nem vagy csak kevésbé jellemzó vonása, hogy növekvố mennyiségú szolgáltatásokat képes generálni csökkenô mennyiségú forrásokból; az új szolgáltatások a számítástechnikai teljesítmény, a tárolási kapacitás és az átviteli teljesítmény (sávszélesség) növelése révén valósulnak meg. A forráskihasználás hatékonyságának 18-24 hónaponként bekövetkezố megkettôződése azért lehetséges, mert az IKT-szektorban az innováció nem magában az anyagban, hanem annak struktúráiban gyökerezik. Az innováció még akkor is elsốsorban az egyre kisebb struktúrák valamilyen ellenốrzött (vagy a jövôben talán önszervezố) módon való előállítását fogja jelenteni, ha egy napon többé már nem a szilíciumot használjuk fel alapanyag-

${ }^{11}$ Az elsớrendú hatásokat néha „közvetlen hatásoknak” nevezik, ennek a terminusnak a használatát azonban nem javasoljuk, mert szemantikailag túl van terhelve. 
ként, hanem valami mást. Ha az ilyen típusú innováció átvihetô lenne más szektorokra is, ez óriási hatásokkal járna.

A miniatürizálásnak megvan az a pozitív hatása, hogy a hardvertermékek nagyobb teljesítményú újakkal való felcserélése elvileg utat nyit más dolgok számára is. A kisebb helyszüikséglet mellett a speciális anyag-és energiaigények is kisebbé válnak. Az IKT-hardver ilyen öndematerializáló jellege a fenntarthatóság irányába mutató trendet eredményezne, ha ugyanakkor nem idézne elő visszacsapó hatásokat is.

Az IKT-eszközök egyre nagyobb teljesítménye iránti igény gyorsabban növekszik, mint a forráskihasználás hatékonysága a hardver szintjén. Ha például egy modern számítógép teljesítménye ezerszerese az elsố számítógépekének, miközben a forrásigényessége ugyanolyan nagyságrendú marad, ez annyit jelent, hogy ha az elmúlt húsz év során megelégedtünk volna a számítástechnikai teljesítmény csupán tízszeres növekedésével az ezerszeres helyett, akkor ténylegesen százszoros forrásmegtakarítást kellett volna elérnünk, mivel néhány évente lecserélhettünk volna minden egyes készüléket kisebb, könnyebb és energiatakarékosabb újakra. Ahhoz azonban, hogy elég messzire jussunk, a kijelzố berendezések és a számítógépet magában foglaló „házak” méretcsökkentését is lehetôvé tevô innovatív interaktív technológiákra („,kiberszemüvegekre”, virtuális billentyúzetekre) lett volna szükségünk.

Ez is megvalósulhat egy napon, mindazonáltal a hatékonyság terén elért haladást eddig ellensúlyozta a „többet ugyanabból” nem túlságosan innovatív követelménye. Ahogyan azonban a források ritkává fognak válni, a visszacsapó hatás is csökkenni fog, úgyhogy az IKT-szektor magas szintú és feltehetốen továbbra is növekvő forráskihasználási hatékonysága fontos hozzájárulást jelenthet a fenntartható fejlődéshez.

\section{Az IKT-hardver életciklusa}

Mindaddig, amíg az IKT-hardver egyre növekvố mennyiségú gyártása, felhasználása és hulladékká válása folytatódik, vagyis a tonna/évben mérhetô anyagáramlás abszolút értékben növekszik, az általa okozott környezeti hatások jelentósége is növekedni fog. Ez nem fog együtt járni olyan általános környezeti hatásokkal, amelyek összehasonlíthatók lennének az építôipari vagy a közlekedési szektoréval, hanem egy nagyságrenddel ez utóbbiak alatt marad. Maga a trend azonban, amely még mindig erôsödik, szükségessé fogja tenni, hogy ökológiai szempontok figyelembevételével folyamatosan elemezzük és optimalizáljuk az IKT-termékek életciklusát. A felhasználók az életciklus hatásait elsósorban a hardver felhasználási idejének kiterjesztésével csökkenthetik.

\section{Másodrendü (másodlagos) hatások}

A másodrendû hatások közé az IKT más folyamatokban való felhasználásából eredố hatásokat soroljuk. ${ }^{12}$ Ezek a „más folyamatok” általában hozzátartoznak a termék életcik-

12 A másodrendú hatásokat „közvetett hatásoknak” is nevezik, ez a terminus azonban szemantikailag túl van terhelve. A termékek életciklusának értékelésében használt terminológia más értelemben tesz különbséget a közvetlen és a közvetett hatások között, mint a fenntarthatóságról szóló jelentésekben és más, ezzel összefüggó területeken használatos terminológiák. 
lusához. Egy IKT-szolgáltatás ennélfogva hatást gyakorol valamilyen másik termék életciklusára, amelyet optimalizál (optimalizációs hatás), illetve amelyet ennélfogva kevésbé gyakran vagy még gyakrabban használnak (szubsztitúciós, illetve indukciós hatás).

\section{Optimalizációs és szubsztitúciós hatások}

A gazdaság négyszeres - vagy akár tízszeres - mértékú dematerializálásához a valódi kulcsot az optimalizációs és szubsztitúciós hatások adják, amelyek ily módon a fenntarthatósági dilemma megoldásának szükséges elófeltételét jelentik.

Az IKT-alkalmazásoknak tulajdonítható optimalizációs és szubsztitúciós hatások azonban ma nincsenek kellóképpen kihasználva, és ezeket néha kiegyensúlyozzák a visszacsapó hatások. A legnagyobb és eddig kihasználatlan optimalizációs potenciál az intelligens lakóterek fútése és hútése terén lelhetô fel, továbbá olyan szolgáltatások létrehozásában, amelyek helyettesítik az anyagi tulajdonviszonyokat. A szubsztitúció egy másik típusa az irodai munkahelyek virtuálissá válása, ami azért válik lehetôvé, mert a személyes munkaterületek egyre inkább függetlenednek a fizikai tértól. Ennek eredménye a létesítmények sokkal hatékonyabb kihasználása, jelentôs közvetett energiamegtakarítás mellett. ${ }^{13}$

A legnyilvánvalóbb visszacsapó hatás a fizikai részvétellel járó értekezletek virtuális megoldásokkal való kiváltása terén mutatkozik meg: az üzleti utazások mennyisége nem csökkent, dacára az audio- és videokonferenciák, a távegyüttmúködés, a CSCWrendszerek ${ }^{14}$ és más „virtualizáló” technológiák terjedésének.

Mindez azonban megváltozhat, ha a természeti eróforrások viszonylagos ára továbbra is emelkedik, különösen akkor, ha az ásványi energia ára az eddigi olajárcsúcs elérése után még tovább nô. Egyszerúen fogalmazva: ha a fútés és a hútés drágábbá válik, akkor az emberek örömmel fogják csökkenteni a költségeket az IKT-eszközökre alapozott optimalizálás révén.

Ha az utazás drágább lesz, az emberek szívesebben beérik majd virtuális kirándulásokkal a kevésbé érdekes utazások helyett. A vitafórumok és a projektmunka nagy távolságok és több idôzóna áthidalásával történô lebonyolítására szolgáló szoftverek minốsége várhatóan ugrásszerúen javulni fog, s ennek következtében ezek a kommunikációs és munkaformák mind jobban beépülnek a mindennapi kultúrába, ahogyan az a telefon esetében is történt, mindössze néhány évtizeddel azután, hogy az új technológia a 19. század végén megjelent.

\section{Indukciós hatások}

Az indukciós hatások közé azokat a másodrendú hatásokat soroljuk, amelyek a fenntarthatósággal összefüggó tényezók miatt okoznak problémákat. Ezeket nem szabad összetéveszteni a visszacsapó hatásokkal. Például a tintasugaras és a lézernyomtatók jelentốs papírfogyasztást indukálnak: ha vásárolunk egy nyomtatót a személyi szá-

${ }^{13}$ Ezt illusztrálja például az IBM Germany „e-munkahelyek” programja, melynek során négy év leforgása alatt majdnem a felére sikerült csökkenteni az egy fớre jutó munkahelyi energiafelhasználás mutatóit (Fichter 2006).

${ }^{14}$ Computer Supported Co-operative Work, CSCW. 
mítógépünkhöz, a papírfogyasztásunk növekedni fog. Ez nem visszacsapó hatás, mivel a nyomtatót nem azzal a szándékkal vesszük meg, hogy takarékoskodjunk a papírral, hanem éppen azért, hogy papírra nyomtathassunk vele.

Az internetnek a mindennapi tapasztalatok alapján még a közlekedés és a teherszállítás terén is vannak indukciós hatásai. A távoli helyeken tartózkodó személyekkel való kommunikáció lehetôsége megteremti mind a szükségletet, mind a szervezési eszközöket újabb üzleti kapcsolatok felvételéhez és utazások lebonyolításához, ami növekvố személy-és teherforgalmat indukál. Az internet csupán az utolsó szemet alkotja a telekommunikációs médiumok láncában, amelyek egyre nagyobb teljesítményưvé váltak már a telegráftól a telefonig és a faxig vezetô fejlődési út megtétele során is.

\section{Harmadrendü (harmadlagos) hatások}

A harmadrendú hatásokat a társadalomnak az IKT-szolgáltatások biztonságosan elérhetôvé válására adott adaptív reakcióiként határozhatjuk meg. Az effajta alkalmazkodás szolgálhatja a fenntarthatóságot, de annak ellenében is hathat. A harmadrendú hatásokat rendszerszintû́ vagy „szisztemikus” hatásoknak is nevezik.

\section{A gazdaság dematerializálódása irányában ható strukturális változások}

Az IKT-szolgáltatások hosszú távon biztosított elérhetôsége kétféle módon is lehetôvé teheti és elôsegítheti a kevésbé anyagigényes gazdasághoz vezetô átmenetet.

- Elốször is lehetôvé válik a környezeti folyamatok sokkal hatékonyabb nyomon követése és jobb megértése, ami remélhetóleg a környezettudatosság magasabb szintjéhez és a környezettel való kölcsönhatásaink, vagyis a társadalom és az ökoszisztémák között lokális, regionális és globális szinten végbemenô anyag-, tömeg- és energiaáramlások hatékonyabb kontrolljához fog vezetni (ebben segít a környezeti információk feldolgozása).

- Másodszor olyan üzleti modellek és életstílusok alakulhatnak ki, amelyekben a termelés és a fogyasztás dematerializálódik, vagyis az értékteremtés elsósorban az új struktúrák létrehozásán alapul, és majdnem teljesen elválasztódik az anyag-és energiaforgalomtól, miközben a fogyasztás a szolgáltatásokra koncentrálódik, és jórészt elválik a fizikai javak hagyományos birtoklásától (ezt nevezik strukturális dematerializációnak).

\section{A körmyezeti információk feldolgozása}

A klímaváltozásra vonatkozóan meglevố ismereteink - bár ma még korlátozottak - numerikus éghajlati modelleken és az ezek futtatásához szükséges számítástechnikai teljesítményen alapulnak. Az IKT-eszközök nélkül az üvegházhatású gázok kibocsátásának csökkentése nem szerepelne a politika napirendjén.

A klímaváltozás csak az egyik területe a gazdasági rendszer és a természet közötti kölcsönhatásoknak. Ahogy azonban globális tevékenységünk ellenốrizetlen kibơvüléséból adódóan egyre közelebb jutunk az ember terjeszkedésének természet szabta korlátaihoz, más területeken is egyre mélyebb ismeretekre és nagyobb tudatosságra volna szükség. 


\section{Strukturális dematerializáció}

A fenntarthatóság eléréséhez elengedhetetlenek a mély strukturális változások, amelyek a gazdaság alapvetó vonásai közé emelik a fent említett helyettesítési hatásokat. Az ily módon dematerializálódó gazdaságban a hozzáadott érték előállítása nem elsốsorban az anyag és az energia ide-oda szállítására, hanem - a jelenleginél sokkal nagyobb mértékben - a megfeleló struktúrák létrehozására épülne.

Egy ilyen hipotetikus gazdasági rendszerben minden ritka anyag megújuló energiával fenntartott zárt ciklusokban mozog. Minden értékteremtés zárt körfolyamatokban megy végbe, melyek során az anyag szerkezete - fizikai tulajdonságainak bizonyos határok között való megórzése mellett - átalakul, ami biztosítja az újrafelhasználhatóságát. Az egész rendszer ilyen zárt körök hálózatából épül fel.

Az IKT-szektor hardver-szoftver dichotómiája általánosítható az egész gazdaságra: a hálózat minden egyes csomópontja tartalmaz egy hardver- és egy szoftverkomponenst (az anyag és az energia átalakításához szükséges termelóeszközöket, illetve a hozzáadott értéket létrehozó átalakítások vezérléséhez szükséges tudást). A nyersanyag, a termék és a hulladék mai megkülönböztetése elavulttá válik, mivel a termelési ciklusoknak nem lesz sem kezdete, sem vége. Az innováció új csomópontoknak a rendszerbe való beillesztését fogja jelenteni.

\section{Visszacsapó hatások és a kritikus információs infrastruktúra kialakulása}

Visszacsapó hatások akkor lépnek fel, amikor valamely szolgáltatás hatékonysága növekszik, de nincs olyan tényezó (például az érte kifizetendő ár vagy az igénybevételéhez szükséges idô), amely korlátozná az iránta megnyilvánuló keresletet. A gazdasági rendszer (a társadalom egyik funkcionális alrendszereként) a kereslet növekedésével alkalmazkodik a szolgáltatás magas hatékonysági szintjéhez.

Ennél is rosszabb azonban, hogy a rendszer nem csupán a nagyobb hatékonysághoz, hanem a szolgáltatás stabil és tartós elérhetôségéhez is alkalmazkodik, és ezáltal attól függớvé válik. Az internet és más IKT infrastruktúrák (például a mobiltelefon-hálózatok) ennélfogva a társadalom kritikus infrastruktúráivá válnak. A kritikus infrastruktúrák védelmének programja (Critical Information Infrastructure Protection, CIIP) olyan új kutatási és gyakorlati területként alakult ki, melynek célja annak biztosítása, hogy az információs infrastruktúrák kevésbé legyenek kitéve esetleges üzemzavaroknak. Az IKT mára behatolt az élet minden területére, többek között a szállítási, energiaellátási, vízellátási, pénzügyi és nemzetbiztonsági infrastruktúrákba is, egyre összetettebbé és egymástól kölcsönösen függóvé, s ennélfogva egyre sebezhetóbbé téve azokat (Hilty 2008). Az IKT-rendszerek tényleges biztonsági vagy sebezhetôségi szintjét - a páratlan komplexitásukból adódó problémák következtében - szinte lehetetlen pontosan meghatározni. Éppen emiatt az általános és mélyen gyökerezố fogyatékosságuk miatt nem lehet kizárni az IKT infrastruktúra ellen irányuló katasztrofális támadások lehetôségét, és éppen emiatt nem lehet pontosan meghatározni az ilyen támadások kockázatának mértékét sem. 
Mindössze annyit tudunk biztosan, hogy változatos szoftverek használata csökkenti a kritikus információs infrastruktúrák sebezhetôségét, míg az egységes szoftverek alkalmazására épülő monokultúra törékenyebbé teszi óket. A nyílt szabványok lehetôvé teszik az interoperabilitás és a változatosság összeegyeztetését azáltal, hogy a „mit?” kérdését együttmúködési folyamatokban döntik el, a „hogyan?” kérdésében pedig a piacra bízzák a legjobb megoldások megtalálását. Ezzel szemben az úgynevezett tulajdonosi szabványok függôvé teszik a fogyasztókat bizonyos termékektôl (lock-in effect), és ezek elterjedése monokultúrák kialakulásához vezet.

A komplexitás csökkentése szempontjából jobban járunk, ha a „mit?” meghatározásához megbízható specifikáció áll rendelkezésünkre, a kivitelezés, vagyis a „hogyan?” terén pedig többféle, egymással versengố megközelítés közül választhatunk (miáltal a kivitelezés konkrét módja lényegtelenné válik, és akár el is rejthetô). Ha viszont valamely rosszul körülírt, egyetlen kivitelezési lehetôséget nyújtó rendszerrel dolgozunk, számolnunk kell azzal, hogy annak valamennyi hibája és biztonsági kockázata több millió alkalommal ismétlódik.

A tulajdonosi szabványokon alapuló kritikus információs infrastruktúrák ennélfogva nem tarthatók fenn. További problémákat okoz ugyanis az a tény, hogy sok kereskedelmi szoftver-termék tele van hintve hibával, melynek következtében rendszeresen felújításra szorulnak, és ez ahhoz vezethet, hogy a hatalom annak a szereplônek a kezében koncentrálódik, akit a legújabb szoftverváltozat legitim szolgáltatójaként ismernek el.

\section{Következtetések és elöretekintés}

A globális információs társadalom kialakulásához vezető átmenet számos lehetôséget biztosít a fenntartható fejlődéshez. A környezeti információk feldolgozása hozzásegít annak jobb megértéséhez, hogy a komplex természeti környezet, amelytól életünk függ, hogyan múködik, és hogyan módosul a társadalom hatásainak kitéve. Emellett támogatja a környezeti kérdésekkel kapcsolatos racionális döntéshozatalt mind a politikában, mind a vállalatirányítás területén. Az úgynevezett „környezeti információs rendszerek” (Environmentel Information Systems, EIS) fenntartása sok területen nélkülözhetetlen a meghozott döntések végrehajtásához is. Az információs társadalom nagy lehetôségeket nyújt a termékek és szolgáltatások dematerializálásához, ami egyenértékú az ökológiai hatékonyság növelésével, és képessé teszi a társadalmat olyan új és vonzó életstílusok kialakítására, amelyek az immateriális szolgáltatások sokaságának igénybevételére épülnek. Az információs technológia azonban csak szükséges, de nem elégséges feltételt jelent a fenntartható fejlódés mint cél eléréséhez. Mint az eddigi fejlemények világosan megmutatták, fennáll az a veszély, hogy ez a technológia ténylegesen több anyag és energia bevitelét és átáramlását okozza a gazdasági rendszerben, mint amennyit megtakarít. Más szóval elófordulhat, hogy a tevékenységi szintjét tonnákban mérố ipari gazdaság szintjén tart bennünket ahelyett, hogy átvezetne a tudásalapú gazdasághoz. A hardver közvetlen hozzájárulása az anyagáramlásokhoz, valamint - ami még fontosabb - a közvetett indukciós és a visszacsapó hatások számos problémát okoznak, amelyekkel szembe kell néznünk. Az pedig, hogy a társadalom az 
információs társadalomhoz vezetô útján hogyan tud fellépni ezekkel a veszélyekkel szemben, tisztán politikai és kulturális kérdés.

A fenntarthatóság csak életstílusunk megváltoztatása révén érhetố el. Több virtuális, immateriális áru és szolgáltatás társadalmi elfogadása valójában kulturális változást jelent. Ez a változás azonban csak akkor következhet be, ha az információs társadalom nem ugyanazoknak a dolgoknak új módon, más közvetítóeszközök használatával való megismétlődését fogja jelenteni számunkra. Az információs társadalmat olyan új gazdasági modellek és szolgáltatások változatos sokaságát elénk vetítố vízióként kell felfognunk, amelyek átalakítják életmódunkat azáltal, hogy lehetôvé teszik a virtuális cselekvést ott, ahol ennek egyértelmú elónyei vannak, miközben meghagyják a valóságos világban mindazt, ami fizikai úton jobban elvégezhetô.

\section{Irodalom}

Avouris, N. - B. Page (eds.) 1995. Environmental Informatics - Methodology and Applications of Environmental Information Processing. Dordrecht, Kluwer Academic Publishers.

Binswanger, M.: 1999. Technological Progress and Sustainable Development: Different Perspectives on the Rebound Effect. Series A Discussion Paper 99-07. Olten, Solothurn University of Applied Sciences.

Bullinger, H.-J. - L. M. Hilty - C. Rautenstrauch - U. Rey - A. Weller 1998. Betriebliche Umweltinformationssysteme in Produktion und Logistik. Marburg, Metropolis.

Cremers, A. B. - K. Greve (Hrsg.) 2000. Umweltinformatik 2000 / Computer Science for Environmental Protection. Umweltinformation fïr Planung, Politik und Öffentlichkeit / Environmental Information for Planung, Politics and the Public. [Marburg], Metropolis.

Denzer, R. -D., Swayne-G. Schimak (eds.) 1997. Second International Symposium on Environmental Software Systems (ISESS), Whistler (Canada). New York, Chapman \& Hall.

Ehrenfeld, J. R.: 1997. Will Information Technology Produce Factor 4-10 Reductions in Energy and Material Consumption? Presented at the European Telematics Conference and Exhibition, Barcelona, February 4-7, 1998. In Geiger et al. (eds.): Umweltinformatik '97, 11. internationales Symposium Informatik für den Umweltschut: Informatique pour l'Environnement 97. Strasbourg 1997. [Marburg], Metropolis.

Fichter, K. 2006. Das „e-place“-Konzept der IBM Deutschland. Fallstudie im Rahmen des nova-net Arbeitsmoduls „Nachhaltigkeit von Innovationsprozessen in der Internetökonomie“. Stuttgart, Fraunhofer IRB Verlag.

Gnauck, A. - Heinrich, R. (eds.) 2003. The Information Society and Enlargement of the European Union. [Marburg], Metropolis.

Günther, O. 1998. Environmental Information Systems. Berlin Heidelberg, Springer.

Haasis, H.-D. - K. C. Ranze (Hrsg.) 1998. Umweltinformatik '98: Vernetzte Strukturen in Informatik, Umwelt und Wirtschaft. 12. Internationales Symposium Informatik für den Umweltschutz, Bremen 1998. [Marburg], Metropolis.

Hilty, L. M. 2008. Emerging Risks in Information Infrastructures - A Technology Assessment Perspective. Proceedings of IDRC 2008. Davos, International Disaster Reduction Conference.

Hilty, L. M. - Gilgen, P. W. 2001. Sustainability in the Information Society. 15th International Symposium Informatics for Environmental Protection, Zurich, [Marburg], Metropolis. 
Hilty, L. M. - C. Rautenstrauch 1997. Environmental Information Systems for Production and Recycling. In Denzer, R. - D., Swayne - G. Schimak (eds.): Second International Symposium on Environmental Software Systems (ISESS). Whistler (Canada), New York, Chapman \& Hall, 21-29.

Hilty, L. M. - D. Schulthess - T. F. Ruddy (eds.) 2000a. Strategische und betriebsïbergreifende Anwendungen betrieblicher Umweltinformationssysteme. Marburg, Metropolis.

Hilty, L. M. - T. F. Ruddy - D. Schulthess 2000b. Resource Intensity and Dematerialization Potential of Information Society Technologies. Series A Discussion Paper 2000-01. Olten, Solothurn University of Applied Sciences.

Hilty, L. M. - Seifert, E.- Treibert, R. (eds.) 2005. Information Systems for Sustainable Development. Hershey (PA), Idea Group Publishing.

Hilty, L. M. - Page, B. - Hrebícek, J. 2006. Environmental Informatics. Environmental Modelling and Software, 21, 1517-1518.

Hrebicek, J.- Racek, J., (Eds.) 2005. EnviroInfo Brno 2005, Informatics for Environmental Protection; Networking Environmental Information. Masaryk University.

Hryniewicz, O. - Studziñski, J. - Romaniuk, M. (Eds.) 2007. EnviroInfo Warsaw 2007 Environmental Informatics and Systems Research. 21st International Conference Informatics for Environmental Protection. Aachen, Shaker.

Isenmann, R: Corporate Sustainability Reporting. In Hilty, L. M. et al: 2005. Information Systems for Sustainability. London, Melbourne, Singapore, Idea Group Hershey, 164-212.

ISF - Information Society Forum, Forum Info 2000: Challenges 2025 - On the Way to a Sustainable World-Wide Information Society. 1998. FAW Ulm.

ITU 2008. Labelle, R. - Ludwig, K. - Rodschat, R. - Vetter, T.: ICTs for e-Environment Draft. International Telecommunications Union (ITU). http://www.itu.int/ITU-D/cyb/ app/e-env.html (Letöltve: 2008. 05. 30.)

Meyer-Abich, K.-M. 2001. Nachhaltigkeit - ein kulturelles, bisher aber chancenloses Wirtschaftsziel. Zeitschrift für Wirtschafts- und Unternehmensethik. Zfwu, 2/3, 291-310.

Minsch, J.- Feindt, P.-H. - Meister, H.-P. - Schneidewind, U. - Schulz, T. 1998. Institutionelle Reformen für eine Politik der Nachhaltigkeit. Berlin-Heidelberg-New York, Springer.

NRP41 - National Research Programme on transport and the environment. 2000, Switzerland.

Page, B. - Hilty, L. M. (Hrsg.) 1995. Umweltinformatik - Informatikmethoden für Umweltschutz und Umweltforschung. Oldenbourg. München et al., 2. Auflage.

Pillmann, W. - Tochtermann, K., (eds.) Environmental Communication in the Information Society, EnviroInfo 2002, International Society for Environmental Protection. Vienna.

Radermacher, F. J. 1996. Die Informationsgesellschaft: Langfristige Potentiale für eine nachhaltige Entwicklung und die Zukunft der Arbeit. Oracle Welt - Die globale Informationsgesellschaft als Chance, 3. S. 36-39.

Rautenstrauch, C. - Patig, S. (eds.) 2001. Environmental Information Systems in Industry and Public Administration. Hershey (PA), Idea Group Publishing.

Rautenstrauch, C. - Schenk, M. (Hrsg.) 1999. Umweltinformatik 99 - Umweltinformatik zwischen Theorie und Industrieanwendung. 13. Internationales Symposium Informatik für den Umweltschut:. [Marburg], Metropolis.

Riekert, W.-F. - L. Kadric 1997. A Hypertext-based Information Retrieval Network for Environmental Protection Regulations. Environmental Material Flow Analysis by Network Approach. In W. Geiger et al. (eds.): Umweltinformatik '97, 11. internationales Symposium 
Informatik für den Umweltschutz - Informatique pour l'Environnement '97, Strasbourg 1997. Marburg, Metropolis.

Schimak G. - Swayne D. - Quinn N. - Denzer R. (eds.) 2003. 5th International Symposium on Environmental Software Systems (ISESS 2003). May 25-27, Semmering, Austria, Environmental Software Systems Vol. 5.

Tochtermann. K. - Scharl, A. (eds) 2006. Managing Environmental Knowledge. 20th International Conference on Informatics for Environmental Protection-Celebrating Two Decades of Environmental Informatics. Shaker.

Scheer, A.-W. - H.-D. Haasis - I. Heimig - L. M. Hilty - M. Kraus - C. Rautenstrauch 1996. Computergestiitzte Stoffstrommanagement-Systeme. Marburg, Metropolis.

Schmidt, M. - A. Möller - J. Hedemann - P. Müller-Beilschmidt 1997. Environmental material Flow Analysis by Network Approach. In W. Geiger et al. (eds.): Umweltinformatik '97, 11. internationales Symposium Informatik für den Umweltschut: Informatique pour l'Environnement 97, Strasbourg 1997. Marburg, Metropolis 768-779.

Schmidt-Bleek, F.: Wieviel Umwelt braucht der Mensch? Gedanken über eine neue Dimension des Umweltschutzes. In L. M. Hilty et al. (eds.) 1994. Informatik für den Umweltschut:. Marburg, Metropolis, 13-36.

Susini, A. - Minier, P. 2004. Sharing. Proceedings of the 19th International Symposium on Environmental Informatics, EnviroInfo 2004. Geneva, CERN, Editions du Tricorne.

Swayne, D. - Denzer, R. - Schimak, G. (eds.) 1997. 2nd International Symposium on Environmental Software Systems (ISESS). Whistler (Canada), New York, Chapman \& Hall, 355-342.

Swiss Experiment. http://www.swiss-experiment.ch/ (Letöltve: 2008. 05. 30.)

Voinov, A. - Jakeman, A.J. - Rizzoli, A.E. (eds) 2006. Proceedings of the iEMSs Third Biennial Meeting: „Summit on Environmental Modelling and Software”. International Environmental Modelling and Software Society. Burlington, USA, July. CD ROM. URL: http://www.iemss.org/ iemss2006/sessions/all.html

WCED - World Commission on Environment and Development 1987. Our Common Future. Oxford, Oxford University Press.

WSIS 2003. World Summit on the Information Society (WSIS) Action Line C7: E-environment. http://www.itu.int/wsis/docs/geneva/official/poa.html\#c7-20 (Letöltve: 2008. 05. 30.) 